ROBUST UNIONISM 


\section{BOOKS BY ARTHUR B. SHOSTAK}

America's Forgotten Labor Organization

Blue-Collar World (with William Gomberg)

New Perspectives on Poverty (with William Gomberg)

Sociology in Action

Blue-Collar Life

Sociology and Student Life

Privilege in America: An End to Inequality? (with Jon Van Til and Sally Bould Van Til)

Putting Sociology to Work

Modern Social Reforms

Our Sociological Eye

Blue-Collar Stress

Men and Abortion (with Gary McLouth and Lynn Seng)

The Air Controllers' Controversy (with David Skocik) 


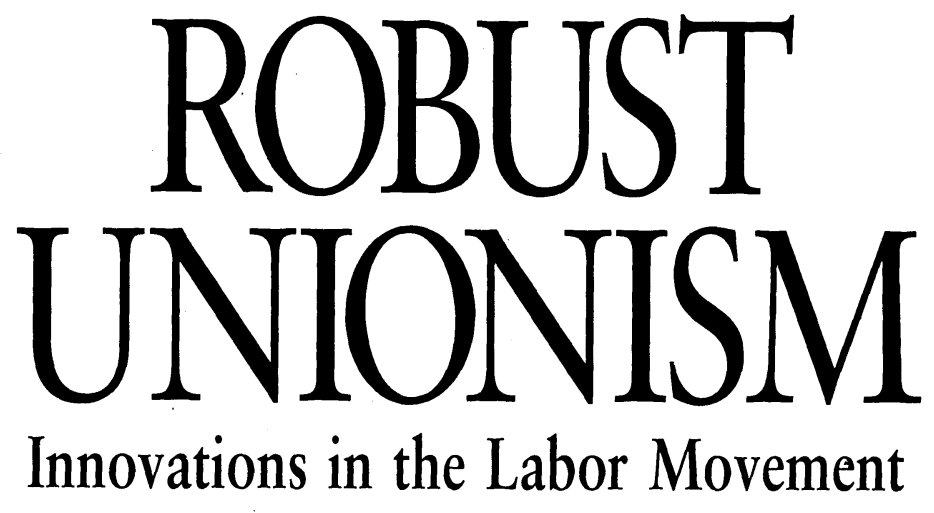

ARTHUR B. SHOSTAK

ILR Press

an imprint of

Cornell University Press

Ithaca and London 
Copyright @ 1991 by Cornell University

All rights reserved. Except for brief quotations in a review, this book, or parts thereof, must not be reproduced in any form without permission in writing from the publisher. For information address Cornell University Press, Sage House, 512 East State Street, Ithaca, New York 14850.

First published 1991 by ILR Press.

Second printing 1992.

Third printing 1995 by ILR Press/Cornell University Press.

Library of Congress Cataloging-in-Publication Data

Shostak, Arthur B.

Robust unionism : innovations in the labor movement / Arthur B. Shostak. p. $\mathrm{cm}$.

Includes bibliographical references and index.

ISBN 0-87546-169-7 (alk. paper).-ISBN 0-87546-170-0 (pbk. : alk. paper)

1. Trade-unions-United States-Case studies. I. Title.

HD6508.S5217 1990

331.88'0973-dc20

$90-47094$

(2) The paper in this book meets the minimum requirements of the American National Standard for Information Sciences-Permanence of Paper for Printed Library Materials, ANSI Z39.48-1984. 


\title{
IN MEMORY OF
}

\author{
I. W. ABEL \\ President of the United Steelworkers of America
}

FRANK W. EMIG

Director of the AFL-CIO Department of Community Services

WILLIAM GOMBERG

Labor consultant and professor of industrial relations, University of Pennsylvania

LEO PERLIS

First director of the AFL-CIO Department of Community Services

BERNARD SAMOFF

Associate professor of management, University of Pennsylvania

Each of these men contributed to this volume shortly before his death, and each modeled a robust life that helped to show the way. 
Royalties from the sale of this book have been assigned to the scholarship fund of the Antioch College degree program at the AFL-CIO George Meany Center in Silver Spring, Maryland. 
I am not unaware of the shortcomings of the labor movement.... They do not seem to me as important or as deeply ingrained in the character of the labor movement [as] the process of social rebuilding which is going on.... a moving force recreating our social organization and achieving a distinctly new pattern.

Frank Tannenbaum, A Philosophy of Labor (1951) 
